\title{
Post exercise cardiovascular effects of different resistance exercise protocols for trunk and upper limbs
}

\author{
Annelise Lins Menêses ${ }^{1}$ \\ Cláudia Lúcia de Moraes Forjaz ${ }^{2}$ \\ Gleyson Queiroz de Moraes Silva ${ }^{1}$ \\ Aluisio Henrique Rodrigues de Andrade Lima ${ }^{1}$ \\ Breno Quintella Farah ${ }^{1}$ \\ Ozéas de Lima Lins Filho ${ }^{1}$ \\ Gustavo Henrique Correia de Lima ${ }^{1}$ \\ Raphael Mendes Ritti-Dias ${ }^{1}$ \\ ${ }^{1}$ School of Physical Education, University of Pernambuco, Recife, PE, Brazil \\ ${ }^{2}$ School of Physical Education and Sports, University of São Paulo, SP, Brazil
}

\begin{abstract}
Objective: to analyze the post exercise cardiovascular effects of different resistance exercise protocols for trunk and upper limbs. Methods: Fifteen males (22.3 \pm 0.9 years) underwent three experimental sessions randomly: control session (C), resistance exercise session at $50 \%$ of one repetition maximum (1$\mathrm{RM})(\mathrm{E} 50 \%)$, and resistance exercise session at $70 \%$ of $1-\mathrm{RM}(\mathrm{E} 70 \%)$. Three sets of 12,9 and 6 repetitions were performed for each exercise. Blood pressure (BP), heart rate (HR) and rate pressure product (RPP) were measured before and during 90 minutes after each session. Results: Systolic BP decreased $(P<.05)$ and diastolic BP increased $(P<.05)$ similarly after $\mathrm{C}, \mathrm{E} 50 \%$ and E70\%. However, HR and RPP decreased after $\mathrm{C}(P<.01)$, maintained after E50\%, and increased after E70\% $(P<.01)$. Conclusions: The resistance exercise intensity did not influence post-exercise BP responses, however, cardiac overload was greater after E70\%.
\end{abstract}

Key Words: Resistance Training. Blood Pressure. Cardiovascular System.

\section{Efeito de diferentes protocolos de exercício de força para o tronco e membros superiores nas respostas cardiovasculares pós-exercício}

Resumo: Objetivo: Analisar o efeito de diferentes protocolos de exercício de força para o tronco e membros superiores nas respostas cardiovasculares pós-exercício. Métodos: Quinze homens (22.3 \pm 0.9 anos) realizaram três sessões de exercício de força para tronco e membros superiores aleatoriamente: sessão controle (C), sessão de exercício de força a $50 \%$ de 1-repetição máxima (1-RM) (E50\%) e sessão de exercício de força a 70\% de 1-RM (E70\%). Foram realizadas três séries de 12, 9 e 6 repetições, respectivamente, para cada exercício. A pressão arterial (PA), a frequência cardíaca ( $F C$ ) e o duplo produto (DP) foram medidos antes e durante 90 minutos após cada sessão. Resultados: a PA sistólica diminuiu $(P<.05)$ e a PA diastólica aumentou $(P<.05)$ de forma semelhante após $\mathrm{C}, \mathrm{E} 50 \%$ e E70\%. Entretanto, a FC e o DP diminuíram após C $(P<.01)$, mantiveram-se após $\mathrm{E} 50 \%$ e aumentaram após $\mathrm{E} 70 \%(P<.01)$. Conclusão: A intensidade do exercício de força não influenciou a resposta da PA pós-exercício, contudo, a sobrecarga cardiovascular foi maior após E70\%.

Palavras-chave: Treinamento de resistência. Pressão Arterial. Sistema cardiovascular.

\section{Introduction}

Resistance exercise has been recommended as part of a training program for the general population (KRAEMER et al., 2002) as well as for subjects with chronic diseases since it promotes several benefits for physical fitness, i.e. gains in muscular size (VERDIJK et al., 2009), strength (BENEKA et al., 2005; SUETTA et al., 2007), and power (CASEROTTI et al., 2008). Due to these benefits, resistance training has also been recommended as part of a comprehensive training for subjects with hypertension (PESCATELLO et al., 2004).

On the other hand, cardiovascular responses to resistance exercise remain poorly known. In fact, blood pressure (BP) responses to resistance exercise have differed considerably among studies. For example, studies have observed a decrease (QUEIROZ et al., 2009; REZK et al., 2006; FISHER, 2001), an increase (O'CONNOR et al., 1993) or a maintenance (RAGLIN et al., 1993) of systolic BP after a single bout of resistance exercise. This controversy was mainly 
caused by the different exercise regimens employed, which make the comparison between studies difficult.

In general, a training program involving 8 to 10 different exercises targeting the major muscle groups is recommended for health maintenance in healthy and hypertensive subjects (AMERICAN COLLEGE OF SPORTS MEDICINE, 2010). In addition, the American College of Sports Medicine suggests that these exercises may be performed using a slip-body approach, in which upper body exercises are performed in one training session and lower body exercise in another (AMERICAN COLLEGE OF SPORTS MEDICINE, 2010). Although this recommendation has been mainly reported for healthy subjects, it may also be applied to hypertensive subjects (AMERICAN COLLEGE OF SPORTS MEDICINE, 2010).

It has been demonstrated that a resistance exercise session including only exercises for the lower body muscles decreases BP during the recovery period (POLITO; FARINATTI, 2009; MACDONALD et al., 1999). However, the impact of upper body exercises on post-exercise BP remains unknown. The only study that analyzed BP responses after upper body resistance exercises observed that 10 sets of arm curl did not cause hypotension in normotensive subjects (POLITO; FARINATTI, 2009). Nevertheless, in this study the exercised muscle mass was very small, which might have limited the post-exercise effects. In addition, a session composed of only one exercise is not used for training in clinical practice. Thus, it is possible that an upper body resistance training protocol that includes more exercises involving larger muscle groups (trunk and arm muscles) would promote post-resistance exercise hypotension, which needs to be studied.

Regarding resistance training protocol, it has been generally accepted that resistance training programs with at least 10 sets (POLITO; FARINATTI, 2009), performed with 6 to 20 repetitions (TEIXEIRA et al., 2010; POLITO; FARINATTI, 2009; QUEIROZ et al., 2009; MELO et al., 2006; REZK et al., 2006; SIMAO et al., 2005; FISHER, 2001) and employing intensities from 40 to $80 \%$ (TEIXEIRA et al., 2010; MELO et al., 2006; REZK et al., 2006) of 1 repetition maximum (1-RM) acutely decreases $\mathrm{BP}$ in both normotensive and hypertensive subjects. However, the magnitude of blood pressure decrease varies a lot among the studies, suggesting that different combinations between intensity and volume might result in different postexercise responses. Nevertheless, previous evidences about the effects of different training protocols on post-exercise hypotension were mainly obtained with training regimens involving exercises for both upper and lower body muscles, being interesting to evaluate different protocols for only upper body exercises.

Therefore, the objective of this study was to analyze the post exercise cardiovascular responses after two different resistance exercise protocols for trunk and upper limbs muscles. Our hypotheses are that both protocols cause postresistance hypotension and that hypotension is greater in the protocol with greater volume and intensity.

\section{Methods \\ Experimental design}

The present study compared acute cardiovascular responses after upper body resistance exercise performed in two different protocols in normotensive subjects: one protocol with 3 sets of 12, 9 and 6 reps with $50 \%$ of $1-\mathrm{RM}$ $(\mathrm{E} 50 \%)$ and the other with 3 sets of 12,9 and 6 reps with $70 \%$ of $1-\mathrm{RM}(\mathrm{E} 70 \%)$. This study was conducted in normotensive subjects in order to analyze the cardiovascular responses to resistance exercise without the influence of any pathological condition.

The subjects performed three experimental sessions in a random order: control (C), E50\% and $\mathrm{E} 70 \%$. Before and during 90 minutes after the experimental sessions $B P$, heart rate $(H R)$ and rate pressure product (RPP) were obtained.

\section{Subjects}

Fifteen males aged between 18-25 years volunteered for the study. Prior to participation, subjects signed an informed written consent. The procedures used in the study were approved by the Institutional Review Board of the Ethics Committee of the University of Pernambuco (223/08).

Subjects were normotensive, non-obese and were not practicing systematic exercise training for at least four months prior to participation in the study, however, all of them reported to have previous experience with the resistance exercises employed in the study. Subjects were excluded if they reported any current disease or medication use. Clinical characteristics of the subjects are presented in Table 1. 
Table 1. Clinical characteristics of the subjects.

\begin{tabular}{lc}
\hline & Mean \pm SE \\
\hline Age, $\mathrm{ys}$ & $22.3 \pm 0.9$ \\
Weight, $\mathrm{kg}$ & $66.5 \pm 1.6$ \\
Height, $\mathrm{m}$ & $1.74 \pm 0.01$ \\
Body mass index, $\mathrm{kg} / \mathrm{m}^{2}$ & $22.0 \pm 0.4$ \\
Resting systolic blood pressure, $\mathrm{mmHg}$ & $110 \pm 2.4$ \\
Resting diastolic blood pressure, $\mathrm{mmHg}$ & $73 \pm 1.8$ \\
Resting mean blood pressure, $\mathrm{mmHg}$ & $85 \pm 1.8$ \\
Resting heart rate, bpm & $75 \pm 2.0$ \\
\hline Values are mean \pm standard error (SE).
\end{tabular}

Values are mean \pm standard error (SE).

\section{Procedures}

As a preliminary evaluation, weight and height were measured and subjects were excluded if body mass index was $>30 \mathrm{~kg} / \mathrm{m}^{2}$. Resting auscultatory systolic and diastolic BP were measured 3 times after $5 \mathrm{~min}$ of resting in two occasions, using a mercury sphygmomanometer (Missouri, Brazil). The mean value between all measures was calculated and applied to determine the subjects' BP level. Subjects were excluded if systolic or diastolic BP were $\geq 130$ and $85 \mathrm{mmHg}$, respectively (CHOBANIAN et al., 2003).

All subjects included in the study underwent two familiarization sessions which aimed to standardize the execution of the resistance exercises included in the study: bench press, bent-over row, frontal raises, arm curl and overhead triceps extension. Subjects performed three sets of 12 repetitions with the minimum load allowed by the equipment in each exercise.

In the subsequent sessions, maximal dynamic strength was evaluated using the 1-RM test. In order to guarantee the accuracy of maximal strength evaluation, all subjects underwent four 1RM test sessions. Subjects performed 1-RM tests at the same time of the day, each one separated by 48 to 72 hours. Before each 1-RM session, subjects were instructed to follow the same recommendations (avoid strenuous physical activities, alcohol, cigarette or caffeine 24 hours before the strength testing and maintain similar sleeping hours and daily activities).

In each exercise, 1-RM test was preceded by a warm-up set (12 repetitions) with approximately $50 \%$ of the estimated load used in the first attempt. After two minutes, subjects were oriented to try to accomplish one repetition with the imposed load in three attempts of each exercise. The resting period between each attempt ranged from two to three minutes. The 1-RM was recorded as the weight of which the subject was able to complete one single execution (CLARKE, 1973). The highest load obtained in the four sessions of each exercise was recorded as the 1RM (DIAS et al., 2005). Exercise technique was standardized and continuously monitored to guarantee reliability in the maximum strength assessment. All sessions were supervised by two experienced researchers for greater safety and integrity of the subjects during the tests.

At least 3 days after the last 1-RM test, subjects underwent, in different days, three experimental sessions in a random order: C, $\mathrm{E} 50 \%$ and $\mathrm{E} 70 \%$. Each session initiated at the same time of the day with an interval of at least 3 days between them. Experimental sessions were scheduled to assure that subjects had a similar routine in all the experimental sessions. Before each experimental session subjects were instructed to follow the same recommendations (take a light meal $2 \mathrm{~h}$ before the experiments, avoid physical exercise and alcohol ingestion for at least the prior 48 hours, avoid caffeine in the previous 24 hours and maintain similar sleeping hours and daily activities).

In each experimental session subjects were referred to a quiet room where they remained resting in the seated position for 20 minutes (preintervention). Meanwhile, BP and HR were measured three times. BP was obtained in the right arm by the auscultatory method using a mercury column sphygmomanometer (Missouri, 
Brazil) and a stethoscope (Techline, Brazil), establishing phases $\mathrm{I}$ and $\mathrm{V}$ of the Korotkoff sounds, respectively, as systolic and diastolic BP. HR was obtained from a HR monitor (Polar, United States) immediately after each BP measurement.

After the resting measurements subjects began the interventions. Exercise sessions were composed of the five above-described exercises. In all the sessions, before each exercise, a 10repetition warm-up set was performed using $25 \%$ of 1-RM. All exercises were performed in three consecutive sets of 12,9 and 6 repetitions, respectively. In the $\mathrm{C}$, subjects exercised with a plastic bar $(0.1 \mathrm{~kg})$ and in $E 50 \%$ and $E 70 \%$ sessions the load of all the exercises were set at $50 \%$ and $70 \%$ of $1-\mathrm{RM}$, respectively. The rest interval between sets was 2 minutes. Subjects exercised in the supine position for the bench press and overhead triceps extension, and seated for the other exercises. All subjects ingested 500 $\mathrm{ml}$ of water while performing the exercises.

After the interventions, subjects returned to the quiet room, where they remained resting in the seated position for 90 minutes (post-exercise). Meanwhile, BP and HR were obtained every 30 minutes following the procedures previously described.

\section{Statistical Analyses}

The sample size was statistically calculated using values obtained in previous studies that observed post-resistance exercise hypotension in normotensive subjects (REZK et al., 2006). The sample size necessary to detect a BP decrease of $4 \mathrm{mmHg}$ with a standard deviation of $1.5 \mathrm{mmHg}$, considering a power of $80 \%$ and an alpha error of $5 \%$, was calculated as 12 subjects. The Gaussian distribution of the data was verified by the Shapiro-Wilk test and the homogeneity of variance was confirmed by the Levene test. BP and HR values obtained in each one of the pre and post-intervention stages were averaged and used for the analysis.

A one-way analysis of variance (ANOVA) was used to compare the baseline value of each variable in the three experimental sessions (C, $\mathrm{E} 50 \%$ and $\mathrm{E} 70 \%$ ). The responses to exercise sessions were analyzed by a two-way ANOVA for repeated measures, establishing sessions (C, $\mathrm{E} 50 \%$ and $\mathrm{E} 70 \%$ ) and stages (pre and post 30 , $60,90)$ as main factors. Post-hoc comparisons were performed by Duncan's multiple range test. $\mathrm{P}<0.05$ was accepted as statistically significant. Data are presented as mean and standard error.

\section{Results}

Five subjects initiated the experimental protocol with the C, seven with the E50\% and four with the E70\%. The 1-RM and the loads used in the resistance exercise sessions are presented in Table 2.

Table 2. Resistance exercise load at different protocols.

\begin{tabular}{lccc}
\hline \multicolumn{1}{c}{ Exercise } & \multicolumn{3}{c}{ Intensity } \\
\cline { 2 - 4 } & 1- RM & 70\% 1-RM & 50\% 1-RM \\
\hline Bench press, $\mathrm{kg}$ & $63.2 \pm 2.8$ & $44.2 \pm 2.0$ & $31.6 \pm 1.4$ \\
Standing row, $\mathrm{kg}$ & $71.5 \pm 2.4$ & $50.0 \pm 1.7$ & $35.7 \pm 1.2$ \\
Frontal raise, $\mathrm{kg}$ & $20.7 \pm 0.6$ & $14.5 \pm 0.4$ & $10.3 \pm 0.3$ \\
Arm curl, $\mathrm{kg}$ & $32.5 \pm 1.5$ & $22.8 \pm 1.1$ & $16.3 \pm 0.8$ \\
Forehead triceps, $\mathrm{kg}$ & $29.9 \pm 1.0$ & $20.9 \pm 0.7$ & $14.9 \pm 0.5$ \\
\hline
\end{tabular}

Values are mean \pm standard error.

The number of repetitions performed in each exercise in the three experimental sessions were similar for all the exercises, except in sets $1(C=$ $12 \pm 0$ and $E 50 \%=12 \pm 0$ vs. $E 70 \%=11 \pm 0$ reps, $\mathrm{P}=.005), 2(\mathrm{C}=9 \pm 0$ and $\mathrm{E} 50 \%=9 \pm 0$ vs. $\mathrm{E} 70 \%=6 \pm 0$ reps, $\mathrm{P}=.003)$ and $3(\mathrm{C}=6 \pm 0$ and $E 50 \%=6 \pm 0$ vs. $E 70 \%=5 \pm 0$ reps, $P=.001)$ of the arm curl exercise, and in sets $2(C=9 \pm 0$ and $\mathrm{E} 50 \%=9 \pm 0$ vs. $\mathrm{E} 70 \%=8 \pm 0$ reps, $\mathrm{P}=.02$ ) and 3
$(\mathrm{C}=6 \pm 0$ and $\mathrm{E} 50 \%=6 \pm 0$ vs. $\mathrm{E} 70 \%=5 \pm 0$ reps, $\mathrm{P}=.02$ ) of the overhead triceps extension. In these sets repetitions were lower in E70\%

Subjects' pre-exercise values of systolic and diastolic BP, HR and RPP were similar among C, E50\% and E70\% (P>.05) (Table 3). The cardiovascular responses to resistance exercise in the three experimental sessions are presented in Figure 1. 
Table 3. Subjects pre-exercise data.

\begin{tabular}{lccc}
\hline & E70\% & E50\% & C \\
\hline Systolic blood pressure, $\mathrm{mmHg}$ & $109 \pm 14$ & $112 \pm 14$ & $112 \pm 12$ \\
Diastolic blood pressure, $\mathrm{mmHg}$ & $70 \pm 8$ & $69 \pm 9$ & $70 \pm 10$ \\
Mean blood pressure, $\mathrm{mmHg}$ & $83 \pm 9$ & $83 \pm 10$ & $84 \pm 10$ \\
Heart rate, bpm & $74 \pm 13$ & $76 \pm 15$ & $75 \pm 14$ \\
Rate pressure product, bpm ${ }^{*} \mathrm{mmHg}$ & $8094 \pm 1241$ & $8483 \pm 1286$ & $8327 \pm 1187$ \\
\hline
\end{tabular}

Values are mean \pm standard error.

In comparison with the pre-intervention values, systolic BP decreased significantly and similarly in the three sessions during all the recovery stages $(\mathrm{P}<.05)$, while diastolic BP increased significantly and similarly in the three sessions during all the recovery stages $(P<.05)$. Mean blood pressure did not change significantly after either experimental sessions $(P>05)$.

In comparison with the pre-intervention values, HR decreased after the $C$ during all the recovery stages $(P<.01)$, decreased after the $E 50 \%$ at 60 min and 90 min $(P<.01)$, and increased after the $E 70 \%$ until 60 min $(P<.01)$. The increases in HR after the $\mathrm{E} 50 \%$ and $\mathrm{E} 70 \%$ were greater than after the $\mathrm{C}$ at all the recovery stages, except at $90 \mathrm{~min}$ in the $\mathrm{E} 50 \%(\mathrm{P}<.05)$. Moreover, the increases in $H R$ after the $E 70 \%$ were greater than after the E50\% at all the recovery stages $(P<.05)$.

In comparison with the pre-intervention values, RPP decreased after the $C$ during all the recovery stages $(P<.01)$, decreased after the $E 50 \%$ at 60 min and 90 min $(P<.01)$, and increased after the $\mathrm{E} 70 \%$ until $30 \mathrm{~min}(\mathrm{P}<.01)$. The increases in RPP after the $\mathrm{E} 50 \%$ and $\mathrm{E} 70 \%$ were greater than after the $C$ at all the recovery stages, except at 60 and $90 \mathrm{~min}$ for $\mathrm{E} 50 \%(\mathrm{P}<.05)$. Moreover, the increases in RPP after the E70\% were greater than after the $\mathrm{E} 50 \%$ at all the recovery stages $(\mathrm{P}<.05)$.

\section{Discussion}

The major findings of this investigation are that (a) a session composed of 5 upper body resistance exercises, performed in 3 sets with 12, 9 and 6 reps with either $50 \%$ or $70 \%$ of $1 \mathrm{RM}$ did not promote a decrease in systolic BP during the post-exercise period; (b) both exercise protocols increased HR and RPP during the recovery period, and these increases were greater after the protocol with higher intensity and volume.

Post-resistance exercise hypotension has been observed in normotensive (POLITO; FARINATTI,
2009; QUEIROZ et al., 2009; REZK et al., 2006; SIMAO et al., 2005) and hypertensive (MELO et al., 2006; FISHER, 2001) subjects after a resistance exercise session including upper and lower body exercises. Moreover, when only lower body exercise is employed, post-resistance exercise hypotension has been also documented (POLITO; FARINATTI, 2009; MACDONALD et al., 1999). On the other hand, this has not been observed after 6 or 10 sets of arm curl (POLITO; FARINATTI, 2009), suggesting that exercising a large muscle mass is necessary for promoting post-exercise hypotension. In the present study, exercises for several muscle groups of upper body were included, and although there was an increase in the active muscle mass, post exercise hypotension was not observed. It suggests that the exercised muscle mass is not the main factor involved in the post-resistance exercise hypotension when upper body exercises are employed.

Although the mechanisms underlying these responses were not analyzed in this study, there are two hypotheses to explain our results. First, the ischemia caused by the mechanical load in the larger arteries during lower limb exercises did not occur during upper and trunk exercises, limiting the stimulus for the release of vasodilator substances. Second, post-resistance exercise hypotension after a session including lower body exercises has been attributed to a decrease in cardiac output, probably mediated by a reduction in the venous return (REZK et al., 2006). In fact, after lower body exercises, vasodilation of the leg muscles might contribute for the decrease in the venous return due to the difficulty of the blood to flow against gravity. On the other hand, when upper body exercises are performed, venous return might not decrease much since vasodilator territory is lower and not very influenced by gravity. 
A
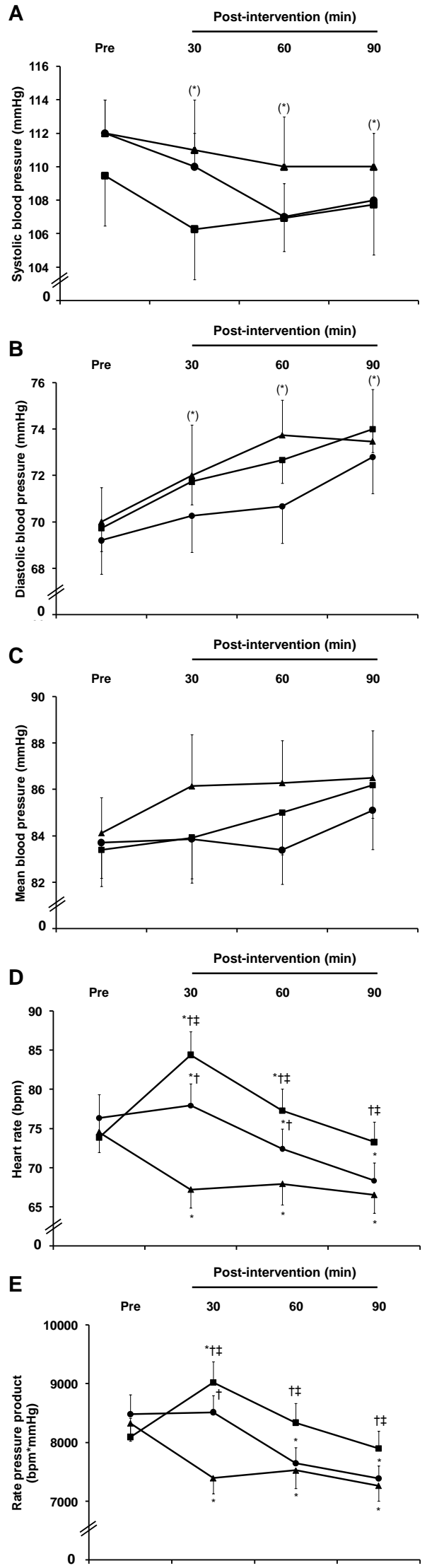

Figure 1. Systolic blood pressure (panel A), diastolic blood pressure (panel B), mean blood pressure (panel C), heart rate (panel D), rate pressure product (panel E) responses observed before (Pre) and after the interventions in the control (triangles), resistance exercise performed at $50 \%$ of $1 \mathrm{RM}$ (circles), and resistance exercise performed at $70 \%$ of 1 RM (squares). * Significantly different from pre exercise $(p<.05) . \dagger$ Significantly different from control. $\ddagger$ Significantly different from exercise at $50 \%$ of 1 RM. ( ) Main stage effect ANOVA.
It is interesting to observe that systolic BP and heart rate decreased throughout time during the control session. This is in contrast with previous studies that showed decrease in post-resistance exercise heart rate, however, no changes in systolic BP were found (TEIXEIRA et al., 2010; REZK et al., 2006). The mechanisms of this response are out of the scope of the present study, but they might be associated to a decrease in cardiac sympathetic activation due to an alert response to the experimental procedure. In addition, the alterations observed throughout time without any intervention highlight the importance of conducting a control session in studies regarding post-exercise hypotension.

Diastolic BP increased similarly in all the experimental sessions. In fact, this increment throughout time when subjects remain seated for a long period has already been reported (QUEIROZ et al., 2009; REZK et al., 2006). It has been attributed to the orthostatic stress imposed by the sitting position, which makes the venous return to the heart difficult, deactivating cardiopulmonary receptors that increase peripheral sympathetic activity, promoting vasoconstriction, increasing vascular resistance and, consequently, diastolic BP (GOTSHALL et al., 1994).

Previous studies have shown that exercise intensity do not affect the magnitude of postresistance exercise hypotension (REZK et al., 2006; SIMAO et al., 2005). Although the protocols differed in both volume and intensity, the results obtained are in agreement with previous findings, showing that the resistance exercise protocol with greater intensity did not affect systolic BP responses after the exercise. On the other hand, $\mathrm{HR}$ and RPP responses were greater and longer after the resistance exercise protocol with a higher volume and intensity. The increase in HR immediately after the resistance exercise has been previously reported (QUEIROZ et al., 2009; REZK et al., 2006), and attributed to an increase in the cardiac sympathetic and a decrease in the parasympathetic modulation in order to compensate the decreases in stroke volume after the exercise session (REZK et al., 2006). Because the $\mathrm{E} 70 \%$ protocol probably resulted in greater cardiovascular stress during exercise, a longer period to HR return to pre-exercise levels was expected. 
The practical application of this study was that the prescription of resistance training session with exclusively upper body exercises is not recommended for promoting post-exercise hypotension. In addition, a protocol with greater volume and intensity did not promote decreases in BP. However, it is important to consider that a resistance exercise protocol including only trunk and upper body exercises might be useful to improve muscle skeletal function, which should be considered depending on the aims of the training.

This study presents limitations that should be considered. First, the American College of Sports Medicine (2010) specific recommendations for hypertensive subjects did not detail the resistance training protocol. Thus, the background of the present study was based on the recommendation for healthy subjects. Second, the sample included only normotensive healthy men, and some of them had a very low resting BP. Therefore, the responsiveness to exercise might have been attenuated since post-resistance exercise BP responses seem to be affected by baseline $\mathrm{BP}$ levels (QUEIROZ et al., 2009; $\underline{\text { MELO }}$ et al., 2006). Thus, future studies should address the responses to upper body exercises in hypertensive subjects. Third, the resistance exercise protocols differed in volume and intensity, thus the influence of each variable separately cannot be determined. Finally, subjects ingested water while exercising, which might have decreased any post-exercise hypotensive effect. In fact, in most of the studies that observed postresistance exercise hypotension the subjects were not allowed to ingest water during experimental sessions (QUEIROZ et al., 2009; REZK et al., 2006). In addition, it has been proposed that water replacement might decrease or even blunt postexercise hypotension after aerobic exercise (CHARKOUDIAN et al., 2003). Thus, it might also affect the BP responses after resistance exercise. However, since in practice many subjects ingested water while exercising, the inclusion of this procedure in the experimental protocol increases the external validity of the study.

In conclusion, the present study revealed that one bout of upper body resistance exercise performed at $50 \%$ or $70 \%$ of $1 \mathrm{RM}$ did not decrease systolic BP during the recovery period. Moreover, these exercise bouts increased both HR and RPP during the post-exercise period, and these responses were higher and lasted longer after the higher volume and intensity protocol.

\section{Referências}

AMERICAN COLLEGE OF SPORTS MEDICINE. Diretrizes do ACSM para os testes de esforço e sua prescrição. Guanabara Koogan, Rio de Janeiro, 2010.

BENEKA, A.; MALLIOU, P.; FATOUROS, I.; JAMURTAS, A.; GIOFTSIDOU, A.; GODOLIAS, G.TAXILDARIS, K. Resistance training effects on muscular strength of elderly are related to intensity and gender. J Sci Med Sport, Belconnen, v.8, n.3, p.274-283, 2005.

CASEROTTI, P.; AAGAARD, P.; LARSEN, J. B.PUGGAARD, L. Explosive heavy-resistance training in old and very old adults: changes in rapid muscle force, strength and power. Scand $\mathbf{J}$ Med Sci Sports, Copenhagen, v.18, n.6, p.773782, 2008.

CHARKOUDIAN, N.; HALLIWILL, J. R.; MORGAN, B. J.; EISENACH, J. H.JOYNER, M. J. Influences of hydration on post-exercise cardiovascular control in humans. J Physiol, London, 0909, v.552, n.Pt 2, p.635-644, 2003. http://ip.physoc.org/content/552/2/635.long

CHOBANIAN, A. V.; BAKRIS, G. L.; BLACK, H. R.; CUSHMAN, W. C.; GREEN, L. A.; IZZO, J. L., JR.; JONES, D. W.; MATERSON, B. J.; OPARIL, S.; WRIGHT, J. T., JR.ROCCELLA, E. J. The Seventh Report of the Joint National Committee on Prevention, Detection, Evaluation, and Treatment of High Blood Pressure: the JNC 7 report. JAMA, Chicago, v.289, n.19, p.2560-2572, 2003.

CLARKE, D. H. Adaptations in strength and muscular endurance resulting from exercise. Exerc Sport Sci Rev, New York, v.1, n.73-102, 1973.

DIAS, R. M. R.; CYRINO, E. S.; SALVADOR, E. P.; CALDEIRA, L. F. S.; NAKAMURA, F. Y.; PAPST, R. R.; BRUNA, N.GURJÃO, A. L. D. Influence of familiarization process on muscular strength assessment in 1-RM tests. Braz $\mathbf{J}$

Sports Med, São Paulo, v.11, n.1, p.39-42, 2005. http://dx.doi.org/10.1590/S1517$\underline{86922005000100003}$

FISHER, M. M. The effect of resistance exercise on recovery blood pressure in normotensive and borderline hypertensive women. J Strength Cond Res, Champaign, 1178, v.15, n.2, p.210-216, 2001.

GOTSHALL, R. W.; ATEN, L. A.YUMIKURA, S. Difference in the cardiovascular response to prolonged sitting in men and women. Can J Appl Physiol, Champaign, v.19, n.2, p.215-225, 1994. 
KRAEMER, W. J.; ADAMS, K.; CAFARELLI, E.; DUDLEY, G. A.; DOOLY, C.; FEIGENBAUM, M. S.; FLECK, S. J.; FRANKLIN, B.; FRY, A. C.; HOFFMAN, J. R.; NEWTON, R. U.; POTTEIGER, J.; STONE, M. H.; RATAMESS, N. A.TRIPLETTMCBRIDE, T. American College of Sports Medicine position stand. Progression models in resistance training for healthy adults. Med Sci Sports Exerc, Madison, 0144, v.34, n.2, p.364380, 2002.

MACDONALD, J. R.; MACDOUGALL, J. D.; INTERISANO, S. A.; SMITH, K. M.; MCCARTNEY, N.; MOROZ, J. S.; YOUNGLAI, E. V.TARNOPOLSKY, M. A. Hypotension following mild bouts of resistance exercise and submaximal dynamic exercise. Eur J Appl Physiol Occup Physiol, Berlin, v.79, n.2, p.148-154, 1999.

MELO, C. M.; ALENCAR FILHO, A. C.; TINUCCI, T.; MION, D., JR.FORJAZ, C. L. Postexercise hypotension induced by low-intensity resistance exercise in hypertensive women receiving captopril. Blood Press Monit, London, 1181, v.11, n.4, p.183-189, 2006.

O'CONNOR, P. J.; BRYANT, C. X.; VELTRI, J. P.GEBHARDT, S. M. State anxiety and ambulatory blood pressure following resistance exercise in females. Med Sci Sports Exerc, Madison, v.25, n.4, p.516-521, 1993.

PESCATELLO, L. S.; FRANKLIN, B. A.; FAGARD, R.; FARQUHAR, W. B.; KELLEY, G. A.RAY, C. A. American College of Sports Medicine position stand. Exercise and hypertension. Med Sci Sports Exerc, Madison, v.36, n.3, p.533-553, 2004.

POLITO, M. D.FARINATTI, P. T. The effects of muscle mass and number of sets during resistance exercise on postexercise hypotension. J Strength Cond Res, Champaign, v.23, n.8, p.2351-2357, 2009.

QUEIROZ, A. C.; GAGLIARDI, J. F.; FORJAZ, C. L.REZK, C. C. Clinic and ambulatory blood pressure responses after resistance exercise. $\mathbf{J}$ Strength Cond Res, Champaign, 1183, v.23, n.2, p. 571-578, 2009.

RAGLIN, J. S.; TURNER, P. E.EKSTEN, F. State anxiety and blood pressure following $30 \mathrm{~min}$ of leg ergometry or weight training. Med Sci Sports Exerc, Madison, v.25, n.9, p.1044-1048, 1993.

REZK, C. C.; MARRACHE, R. C.; TINUCCI, T.; MION, D., JR.FORJAZ, C. L. Post-resistance exercise hypotension, hemodynamics, and heart rate variability: influence of exercise intensity. Eur J Appl Physiol, Berlin, v.98, n.1, p.105-112, 2006. http://dx.doi.org/10.1007/s00421-006-0257y
SIMAO, R.; FLECK, S. J.; POLITO, M.; MONTEIRO, W.FARINATTI, P. Effects of resistance training intensity, volume, and session format on the postexercise hypotensive response. J Strength Cond Res, Champaign, 1169, v.19, n.4, p.853-858, 2005.

SUETTA, C.; MAGNUSSON, S. P.; BEYER, N.KJAER, M. Effect of strength training on muscle function in elderly hospitalized patients. Scand $\mathbf{J}$ Med Sci Sports, Copenhagen, v.17, n.5, p.464472, 2007. http://dx.doi.org/10.1111/i.1600$\underline{0838.2007 .00712 . x}$

TEIXEIRA, L.; RITTI-DIAS, R. M.; TINUCCI, T.; MION JUNIOR, D.FORJAZ, C. L. Post-concurrent exercise hemodynamics and cardiac autonomic modulation. Eur J Appl Physiol, Berlin, v.111, n.9, p.2069-2078, 2011.

VERDIJK, L. B.; GLEESON, B. G.; JONKERS, R. A.; MEIJER, K.; SAVELBERG, H. H.; DENDALE, P.VAN LOON, L. J. Skeletal muscle hypertrophy following resistance training is accompanied by a fiber type-specific increase in satellite cell content in elderly men. J Gerontol A Biol Sci Med Sci, Washington, v.64, n.3, p.332-339, 2009. http://dx.doi.org/10.1093/gerona/gln050

This study was supported by Programa de Fortalecimento Acadêmico da Universidade de Pernambuco (PFA-UPE) and presented at III Congresso Brasileiro de Metabolismo, Nutrição e Exercício (May 2010, Londrina, PR, Brazil).

Corresponding author:

Raphael Ritti-Dias, PhD

School of Physical Education, University of

Pernambuco

Rua Arnóbio Marques, 310, Santo Amaro

Recife PE Brazil

50100-130

Telephone: 558134236433

Fax: 558134236310

e-mail: raphael.dias@upe.br

Received: May 31, 2011.

Accepted: August 23, 2011.

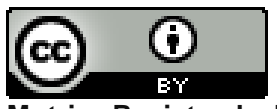

Motriz. Revista de Educação Física. UNESP, Rio Claro, SP, Brasil - elSSN: 1980-6574 - está licenciada sob Creative Commons - Atribuição 3.0 